\title{
Environmental Metaphors in Randai Traditional Performance in Minangkabau: Ethnographic Study
}

\author{
Riskia Siiti Velini ${ }^{1 *}$, Deli Nirmala ${ }^{2 *}$ \\ ${ }^{1}$ Department of Linguistics, Faculty of Humanities, Diponegoro University, Semarang, Indonesia \\ ${ }^{2}$ Department of Linguistics, Faculty of Humanities, Diponegoro University, Semarang, Indonesia
}

\begin{abstract}
Minangkabau Randai is one of the traditional arts from West Sumatera, Indonesia that combines four different aspects: silat, theater, music and dancing. The purpose of Randai is to spread moral values of Minangkabau tradition by using a story called kaba. This research discusses the communication patterns used in Randai. Descriptive qualiative method is used in the research and the data collection is done by doing library research. Because of the COVID-19 pandemic, Randai could not be performed and thus the data are taken from video recording. The title of the Randai performance discussed is Rambun Pamenan and ethnography of communication approach is used to analyze the data by using Hymes' theory of unit of analysis. The result of the research shows that the communicative event takes place on an open field and there are five communicative events done by the speakers: the opening of Randai, the opening for $k a b a$, dendang, the play for kaba and closing. The communicative acts in the play for kaba are in the form of dialogue, which contain verses and environmental metaphors. The position of women in Minangkabau culture is represented through the environmental metaphors in the dialogue.
\end{abstract}

\section{Introduction}

West Sumatera has many traditional arts, and one of them is Minangkabau Randai. There are four types of arts in Randai performance: theater, music, dancing, and silat, a traditional martial art. Randai is performed by a group of people who make a circular form and stomp, while others who act as actors do a play based on the story being performed. This traditional performance is held before Ramadan and usually is at an open field called Medan Bapaneli. However, performing it in a room is also common nowadays, and the place is called Medan Balinduang. There are four aspects in a Randai performance, including the story or kaba, dialogue, acting, traditional verses called gurindam or dendang, and galombang or the circular form.

\footnotetext{
* Corresponding author: veliniriskia@gmail..com
} 
Randai is led by someone whose job is to give a sign to the dancers by yelling some specific words to synchronize the dancers. The leader is called Sang Goreh or Panggoreh. In addition, the dancers for Randai include 6 to 12 people and some others whose job is to make the music and act for the kaba. The performance is usually performed at night and could last all night long nonstop, however in today's society, Randai takes place for 3-4 hours.

The stories for Randai were taken from the daily lives of the locals. The purpose of Randai, besides giving entertainment, is a medium to deliver local wisdom and values to the audience. The story in Randai is called kaba in the Minangkabau language. It is in the form of lyrical prose. The values in kaba vary, starting from the value in how to do in life, in sociocultural, in the household, and the neighborhood. There are some common kaba to be played in Randai, for example Cindua Mato, Malin Deman, Saban nan Haluih, Galombang Dune, Lareng Simawang Jo si Siti Jamila Maleo Rambuik dalam Tampuang, Anggung nan Tongga and others.

The communication pattern in Randai performance is interesting to study using the Ethnography of Communication approach. The dialogues in the performance are full of local wisdom, which is delivered through beautiful verses. Ethnography of Communication is an interdisciplinary study between linguistics and anthropology. The focus of this study is on the speech community. A speech community is a group of people who share the same ideology and presuppositions in a speech act (Sherzer in Saville-Troike, 2002). In addition, the speech community also shares the same attitude and belief toward the language they use. Gumperz (1972) states that speech community is limited to some social units, for example, countries, tribes, religion, or even ethnic groupings.

According to Hymes (in Saville-Troike, 2002), there are three units of analysis in ethnography community: communicative situation, communicative events, and communicative acts. A communicative situation is a situation in which communication occurs. One situation could happen in a different location simultaneously, and in the opposite, there is a possibility of more than one event occurring in one place. Saville-Troike (2002: 23) gives an example where a university building could be used to study, have committee meetings, or be an exercise place. All of them have three different communicative situations even though they occur at the same place. However, one communicative event could occur in more than one place; for example, a trial could be conducted in different places.

In addition, communicative events are the central unit needed for the description. A communicative act can be defined as similar units, including the general purposes, topic, participants, language variety, tone and key, rules, and setting. An event is ended if there is a significant change in participants or setting. Usually, the gap between events is signaled by a few seconds of silence or a specific gesture. However, the event could be continued if the participants resume the conversation with no significant changes in the components.

The last unit of analysis, according to Hymes, is a communicative act. It is usually limited with an interactional function, such as statement, order, request, and command, which could be verbal or nonverbal. For example, when a student wants to borrow a notebook from her friend, it could be expressed by verbal communication such as can I borrow your notebook, or by using nonverbal communication such as giving gestures. According to Saville-Troike (in Saville Troike, 2002: 24), silence could be used as a communicative act and used for different purposes such as questioning, promising, denying, giving warning, insulting, and others.

A previous study has been conducted related to this topic. Azzahro (2018) has done an ethnography of communication research on a traditional game called Oray-Orayan by using the theory of communication components SPEAKING by Hymes and the interrelated component by Saville Troike. The discussion results show that syair in traditional games 
has stage power and ritual power. In ritual power, the components of communication are all found, matched with Hymes' theory. However, in the stage power, the components found are only Ends, Acts, and sequence, Norms, and Participants.

Jaeni (2012) uses an anesthetics communication approach in analyzing a traditional theater performance from Cirebon. She found that there are sociocultural values and feelings and experiences values in the performance. In addition, aesthetical values are the interpretation and expression of the beliefs and values of the locals in sociocultural life.

Fitriyani, Adil, and Bukhori (2020) studied the ritual of Kembar Mayang using an ethnography of communication approach. However, they also used symbolic interactionalism with qualitative and constructivist paradigm approaches. It is found that the communication patterns in the Kembar Mayang ritual are one-way communication and two-way communication. Moreover, the communication types found in the ritual are horizontal and vertical communication styles, verbal and nonverbal. The communication functions are ritual communication and social communication.

Another local ceremony that has been studied using ethnography of communication approach is the symbol displayed in Ngeuyeuk Seureuh Ceremony by Kurniasih (2013). She used the theory coming from Hymes and Saville-Troike about the components of communication. In this Sundanese traditional ceremony, it is identified that there are sociocultural rules in the Ngeuyeuk Seureuh ceremony, for example, how the speech community expresses the local values by displaying symbols through the ceremony and what the meanings are behind it.

The ethnography communication study of Randai has been done before by Putri, Salam, and Yasir (2020). However, the type of Randai is different from this study. They studied Randai from Kuantan Singingi, Riau. The study results show that ethnography's symbolic meanings are found in the performance, including local wisdom and values. The local wisdom and values identified are religious, social, democratic, independent rights, and solidarity.

Maryelliwati et al. conducted a study related to Randai also. They studied maintaining Minangkabau culture in Randai based on education and tourism. This study shows that the younger generation is interested in reproducing the documentation of Silek in Randai for educational purposes or even trading it as a cultural asset.

Husmiwati (2015) has researched traditional culture using ethnography of communication. She studied the communication pattern in Basiacuang traditional wedding ceremony in Melayu Kampar, Riau. This study shows that this tradition is a form of local wisdom in Kuok, Kampar. In addition, there is three communication pattern found in the ceremony, including the communicative situation, communicative events, and communicative acts.

Based on the previous studies, it can be concluded that Randai Minangkabau has not studied yet using ethnography of communication approach. This local performative art has unique communication patterns compared to other local arts in Indonesia. Even though a theater play is integrated into Randai, the language use is not a casual or daily language of Minangkabaunese. They use pantun, gurindam, and metaphors in the dialogue. Thus, the research question of this paper is how the communication used in Randai Minangkabau is.

\section{Research Method}

Based Based on the purpose of the research, the qualitative method is used in this research. The speech events of Randai and environmental metaphors of kaba from the data analysis are described systematically based on the facts. The data was collected by using observation and taking notes. These data then are discussed using the ethnography of communication approach-Hymes' theory about the unit of analysis. In addition, the data 
collection is library research because randai Minangkabau cannot be performed during this COVID-19 pandemic. Thus, the source of data was taken from a video recording. The data were collected from a platform of video sharing called YouTube. The title of the performance analyzed in this paper is called Randai Rambun Pamenan. It is a story of a widow named Puti Linduang Bulan whose husband is recently passed away. She then lives with her two children alone, Puti Rono Pinang and Rambun Pamenan. One day, a king named Rajo Angek Garang from the next district came to her house and asked her to marry him.

To collect and analyze the data, there are several steps. First, the researcher observed by watching the full performance of Randai. During the observation, the researcher took notes about the communicative situation; events act in the performance. When the researcher finished taking notes, the next step was to transcribe the data. Then the data were analyzed using the unit of analysis theory and components of communication theory.

\section{Results and Discussion}

\subsection{Unit of Analysis}

Hymes (in Saville-Troike, 2002) explained three units of analysis, including communicative situation, communicative events, and communication acts. This theory is used to analyze the data in this paper.

\subsubsection{Communicative Situation}

Randai Rambun Pamenan was held on Friday, January 6th, 2017, in an open field at noon. There were 16 people whose job was to dance Randai, two singers, four main actors and actresses, and four supporting roles in the drama. The main characters in the drama are including Rajo Angek Garang, Puti Linduang Bulan, Rambun Pamenan and Puti Rono Pinang. In addition, four more characters are the warriors and play some parts, namely Panglimo Taduang, Pandeka Ampeng Basi, Pandeka Maruntun Manau, and Pandeka Panglimo Bajau.

\subsubsection{Communicative Events}

The communicative event's goal is to describe clearly the situation that occurs in the communicative situation. In Randai Rambun Pamenan, there are five different communicative events, including the opening of the performance, the opening for kaba, dendang, the play for kaba, and the closing.

For the performance's opening, one of the randai performers called Sang Goreh, whose job is to lead the randai dancers, opened the show by singing gurindam. Gurindam is a kind of poetry from the local area with a rhyme in every stanza. The purpose of this event is to tell the audience that the performance will be started soon. After Sang Goreh finished the opening, one of the randai performers opened the kaba by reading a paragraph of verses. The verses contain some pantun to address the audience, particularly the good audience present at the time. The next event is dendang. Two persons sang dendang, or a traditional song from Minangkabau. This event does not occur just once during the whole performance, but it occurs several times, including between changing the scene of the play. The play for kaba itself is entitled Rambun Pamenan. It is a story about a kindhearted and beautiful widow named Puti Linduang Bulan. Her husband had just passed away, and she had to raise her two children, Puti Rono Pinang and Rambun Pamenan, by herself. One day, 
a king from Camin Taruih came to Puti Linduang Bulan and asked her to marry him, but she refused. Because he did not get what he wanted, Rajo Angek Garang was mad and took her to his palace forcibly. Another communicative event is the closing of randai performance.

\subsubsection{Communicative acts}

The communication act discussed is the one found in the dialogue of the play for kaba. It is chosen because communicative acts are found the most in this event, and there are two ways of communication between the characters of the story. There are three main communicative acts in the play for kaba Randai Rambun Pamenan, including when Rajo Angek Garang proposed to Puti Linduang Bulan to be his bride, when Puti Linduang Bulan asked her daughter to take care of her brother - Rambun Pamenan, and when Puti Linduang Bulan arrived at Rajo Angek Garang's palace. In each communication act, there are different forms of communication.

The first communication act occurred when Rajo Angek Garang asked Puti Linduang Bulan to marry him. In this act, there are some communication patterns found. The first one is the communication of Rajo Angek Garang asking Puti Linduang Bulan to marry him. There is an apology from Puti Linduang Bulan before she started to have a conversation with Rajo Angek Garang as shown in the datum (1):

(1) Puti Linduang Bulan:

Ampunlah ambo dek tuan

sorry I of my Lord

'I seek for your forgiveness my Lord'

Ampun baribu kali ampun

forgiveness a thousand times forgiveness

'a thousand of forgiveness'

Disusun jari nan sapuluah

stack fingers that ten

'the ten fingers are stacked'

Ditakuakan kapalo nan satu
bowed head that one
'the head is bowed'

Dihunjuangkan lutuik nan duo

put knees that two

'both knees are on the ground'

Sakali kawak baribu ampun

Once thousand sorry

'a thousand fogiveness at once'

From the communication act (1), it can be seen that there is a form of respect from Puti Linduang Bulan. In the context of kaba, Puti Linduang Bulan is only a resident of a village but on the other hand Rajo Angek Garang is the king of a place called Camin Taruih. From the dialogue, there is a form of respecting someone who has a higher position than the speaker in Minangkabau culture. Puti Linduang Bulan, as a speaker, asked for forgiveness before starting to have a conversation with the interlocutor, Rajo Angek Garang by saying 
ampun lah ambo dek tuan, ampun baribu kali ampun, disusun jari nan sapuluah, ditakuakan kapalo nan satu, dihunjuangkan lutuik nan duo, sakali kawak baribu ampun 'I'm seeking for your forgiveness oh my Lord, a thousand of sorry I ask to you, the fingers are stacked, the head is bowed, the knees are on the ground, thousands of forgiveness at once'. The speaker shows respect to the interlocutor by using expression ampun lah ambo dek tuan, ampun baribu kali ampun which means 'I'm seeking for your forgiveness oh my Lord, a thousand of sorry I ask to you'. In Minangkabau, it is a culture of its people to ask for forgiveness to someone who is older or has a higher position than the speaker.

Another communication pattern found in the first act is a proposal from Rajo Angek Garang, as it can be seen from datum (2) :

(2) Puti Linduang Bulan:

Kambanglah bungo di muaro,

Bloom flower in estuary

'the flowers are bloom in the estuary'

Nampak nan dari batu laui,

See that from rock sea

'are seen from the rock on the sea'

Bukan si Linduang anggan manarimo,

Not Linduang not accepted

'I am not saying that I want to refuse'

Tagah dek ambo barusuah hati,

no of me worried heart

'my heart is saying no'

Tundiang sagitu dari ambo, that much from me

'that is from me'

Tulang maklum pado tuanku

please understand from my Lord

'I hope you can understand my Lord'

Rajo Angek Garang came to Puti Linduang Bulan with an intention to make her to be his wife. He asked her to use a formal register. However, she refused the proposal using pantun. Pantun is a traditional oral poetic form that is used to express ideas. It is usually rhymed on ABAB or AABB. Pantun consist of two parts: a prefatory statement or sampiran and a closing statement called isi. Sampiran does not correlate with isi. In this context, Puti Linduang Bulan used rhymes ABAB in her dialogue kambanglah bungo di muaro, nampak nan dari batu laui, bukan si Linduang anggan manarimo, tagah dek ambo barusuah hati. In this pantun, the prefatory statement is kambanglah bungo di muaro, nampak nan dari batu laui and the closing statement is bukan si Linduang anggan manarimo, tagah dek ambo barusuah hati. Puti Linduang Bulan expresses her refusal through pantun and asks for understanding from the interlocutor by saying tundiang sagitu dari ambo, tulang maklum pado tuanku. The speaker's last speech shows that she is a polite woman because even though she rejected the proposal, she said that politely and nicely without any harsh tone.

The second communication act is a conversation between Puti Linduang Bulan and Puti Rono Pinang. The context in this communication act is that the speaker, Puti Linduang 
Bulan, is about to leave her children and come with Rajo Angek Garang to his palace. Thus she asked her older daughter, Puti Rono Pinang, to care for her younger brother Rambun Pamenan. First, the speaker called the interlocutor, Puti Rono Pinang, to the stage.

\section{(3) Nak kanduang si Rono Pinang daughter biological the Rono Pinang 'My dear Rono Pinang'}

\section{Sangkutannyo batang tumbuah hook trunk growing \\ 'Someone who is reliable'}
(4) Limpapeh rumah nan gadang butterfly house the big 'An important person in Rumah Gadang'

In this communication act, there are two environmental metaphors used by the speaker. The first one is as in datum (3). The speaker described her daughter as a hook of a growing trunk in a tree. The metaphor can be interpreted as someone responsible. A tree trunk is a person who is still growing up and needs someone to look up to, and the hook's job is to guide the trunk for a better future. The trunk can be interpreted as a child or even someone who still needs guidance in their life. However, it is not only limited to a childadult relationship in this context. It also could be in a different context, such as in a community. As her mother, Rono Pinang is a girl who will soon be a woman, and Puti Linduang Bulan wishes her to be a reliable person, especially to another person. In Minangkabau culture, they value women more than anything else, and in this case, the speaker is hoping that her daughter can be a respectful person by being someone whom other people can rely on.

Another metaphor mentioned by the speaker is in datum (4). This is one of the old proverbs in Minangkabau culture. Limpapeh, in the Minangkabau language, is a type of butterfly. It is big and has a beautiful pattern on its wings. According to Minangkabaunese, when there is a butterfly in their house, it means that a woman will visit the house, and that is why a butterfly represents a woman in their culture. In addition, rumah nan gadang is a traditional architecture from Minangkabau. Rumah nan gadang is a vast house where several families share the building and live together, which is common in the culture. Thus, limpapeh rumah nan gadang could be interpreted as an independent, classy, and beautiful woman whose job is to take care of family and community. The speaker, Puti Linduang Bulan, once again described her daughter using a metaphor.

The speaker used another communication pattern. She asked for a favor from the interlocutor to take care of someone because she would be gone for a very long time.

(5) Puti Linduang Bulan :

Kok sampai mandeh ndak namuah pai, bacarai badan jo kapalo

If only mother not want to come, scattered body and head

'If I am not coming, I will get killed'

In datum (5), there is also the use of metaphor found in the clause. Puti Linduang Bulan described how terrifying the situation would be if she resisted Rajo Angek Garang's order. The literal meaning of bacarai badan jo kapalo is that the body and head will be scattered; however, in this situation, we cannot interpret Puti Linduang Bulan's speech as a literal meaning. Her body and her head would not be scattered. She used a metaphor in her speech, and the metaphor could be interpreted as getting killed. The purpose of using metaphor in this context is to make it not so obvious what would happen so the interlocutor would not get scared. In other words, the metaphor here is used to give an indirect speech. 
Another communication pattern identified in the second communicative act is Puti Rono Pinang worried about what will happen in the future. In this act, Puti Rono Pinang, as the speaker explained that she is worried about her brother's future if their mother goes to Rajo Angek Garang's palace. Puti Linduang Bulan as the mother, then answers her concern wisely.

(6) Puti Rono Pinang:

raminyo pasa urang Pangkalan, crowded market people Pangkalan

'Pangkalan market is so crowded'

hari nan sadang pukua satu,

day that is $1 \mathrm{PM}$

'It is $1 \mathrm{PM}$ '

kok auih Rambun Pamenan,

if thirsty Rambun Pamenan

'If Rambun Pamenan get thirsty'

ka sia nyo ka mintak susu

yo whom to ask milk

'to whom he is going to ask for

breastmilk'
(7) Puti Linduang Bulan:

rami nak pasanyo rang

Pangkalan,

crowded that the market people

Pangkalan

hari nan sadang pukua satu,

day that is $1 \mathrm{PM}$

'It is $1 \mathrm{PM}$ '

kok jadi nak mandeh bajalan,

if so that Mother walk

'If I went away'

ambiaklahaia kaganti susu

take water replace milk

'Take the water to replace the breastmilk'

In this communication, both speakers use pantun to express what is in their mind and it rhymes as ABAB. Puti Rono Pinang asked her mother who would give her little brother breastfeed if their mother is gone to somewhere far. It is expressed in datum (6). Puti Linduang Bulan then answer with her speech in datum (7). She said that if she is really gone, then Puti Rono Pinang should replace her breastmilk with water only. It means that even though she is not there anymore for Rambun Pamenan, he could still live by drinking water.

The last communication act in the play is when Puti Linduang Bulan is finally taken to Rajo Angek Garang's palace. She is once again asked to be his bride but still managed to refuse the proposal. In this act, it shows how the marriage tradition in Minangkabau culture works.

(8) Rajo Angek Garang :

Kito baralek hanyo aik,

We wedding only

'We will throw a simple wedding only'

alek banamo alek kawin

alek called alek marriage

'The wedding is called alek'

dibantai kabau tujuah ikua, slaughtered buffalo seven

'Seven buffalos will be

slaughtered'

dipanggia niniak jo mamak,

called niniak and mamak

'Niniak and mamak will be called'

kito baralek tujuh hari,

we wedding seven days

'We will have the wedding for

sarato urang nan banyak

even people that a lot seven days' 
Rajo Angek Garang asked the interlocutor, Puti Linduang Bulan, to be his wife. There are four marriage traditions of Minangkabaunese to be noticed here. The first one kito baralek tujuh hari 'we will have a wedding party for seven days straight. This is a tradition of Minangkabaunese, a wealthy family, like the speaker, Rajo Angek Garang. The speaker is a king, and he wanted to show people how rich he is by throwing a party for a week nonstop. The second tradition is dibantai kabau tujuah ikua'seven buffalos will be slaughtered'. This tradition somehow is still related to the first tradition mentioned before, in which this is only happening in a wealthy family. Slaughtering buffalo is a way for Minangkabaunese to show their gratitude because something important happens, including a marriage. One buffalo costs much money, and thus seven buffalos mean that the family must behave much money, just like the speaker, Rajo Angek Garang.

Another tradition of Minangkabaunese marriage is represented in dipanggia niniak jo mamak, sarato urang nan banyak 'niniak mamak will also be there, along with a lot of people as the guests'. In Minangkabau culture, niniak jo mamak is someone important in the community. He holds a high position in the community, which is similar to a leader. In other words, niniak jo mamak is a respected person, and they are invited to the wedding to give their blessings to the couple. The presence of this public figure at a wedding means that the newlyweds must be essential persons. In addition, sarato urang nan banyak means that there will be many people invited to the wedding party. The speaker wanted to hold a big ceremony to celebrate his marriage with the interlocutor, Puti Linduang Bulan, so he invited as many people as possible.

Because Puti Linduang Bulan kept being stubborn and did not intend to remarry, Rajo Angek Garang was pissed. He was mad at her and asked his pandeka 'soldiers' to lock her up in prison.

(9) Rajo Angek Garang : masuakkan inyo panjaro basi, Put her cage iron 'put her in a prison'

$\begin{aligned} & \text { dilihia rantai bagaluang, } \\ & \text { on neck chain round up } \\ & \text { 'put some chains around her neck' }\end{aligned}$
di pinggang barantai pulo,
on waist chained also
'her waist is also chained'

makan sakandang manyo babi, eat cage pig 'eat with pigs on a cage' minum sasayak nan ayam drink little like chicken 'drink a little a chicken'

From datum (9), power abuse is shown in the dialogue. The speaker, Rajo Angek Garang used his power and domination to abuse the interlocutor, Puti Linduang Bulan, because she kept refusing his proposal. He used the phrases masuakkan inyo panjaro basi, di lihia rantai bagaluang, di pinggang barantai pulo, makan sakandang manyo babi, minum sasayak nan ayam. These phrases are not supposed to be used by someone who is respected by the whole country. The sentences makan sakandang manyo babi, minum sasayak 'eat with pigs in a cage, drink a little like a chicken' do not reflect a language of a king.

\section{Conclusions}

After analyzing the data, it is found that there are five communicative events in Randai Rambun Pamenan. These events include the opening of the performance, the opening for 
kaba, dendang, the play for kaba, and the closing of the randai performance. The communicative act discussed is the play for kaba because the majority of communication occurs in this act. In this communicative act, there are three primary communication patterns: Rajo Angek Garang proposed to Puti Linduang Bulan, Puti Linduang Bulan asked her daughter to take care of Rambun Pamenan, and Puti Linduang Bulan is finally taken to Rajo Angek Garang's place. Each of these events uses a different pattern of communication and contains local values and culture.

The language used in the communicative act of kaba Rambun Pamenanan for the play varies. The majority of dialogues used pantun. Meanwhile, some others use metaphors, and Minangkabau culture is shown through the dialogues. The important points to highlight about this culture are: (1) Minangkabaunese ask for forgiveness from the interlocutor before starting a conversation, especially if the interlocutor has a higher social position than the speaker, (2) women in Minangkabau are treasured well because they are essential to the society and (3) in Minangkabau marriage tradition, they are thankful for the marriage and express it by slaughtering buffalos, and they also invite niniak and mamak to bless the marriage.

\section{References}

1. E. Kurniasih. Peragaan Simbol dalam Upacara Ngeuyeuk Seureuh (Kajian Etnografi Komunikasi) (2013)

2. Fitriyani, M. Adil, K.A. Bukori. I, 26, 2 (2020)

3. Jaeni. JSBP, 22, 2, 160-168 (2012)

4. J.J. Gumperz, D. Hymes. Directions in Sociolinguistics: The Ethnography of Communication (1972)

5. K. Husmiwati. JFISIP, 2, 1, 1-15 (2015)

6. M. Saville-Troike. The Ethnography of Communication: An Introduction. (2002)

7. Maryelliwati, W. Rahmat, K. Anwar. JIS, 1, 2, 44-53 (2019)

8. N. Azzahro. Kajian Etnografi Komunikasi Terhadap Permainan Oray-Orayan Sebagai Kaulinan Barudak Jeung Kawih (2018)

9. T.D. Putri, N.E. Salam, Yasir. JIK, 9, 3, 284-301 (2020)

10. W. Rahmat. JIT, 10, 4, 236-241 (2016) 